\title{
Do Mast Cells Contribute to the Antifungal Host Defense?
}

\author{
Paulina Żelechowska ${ }^{1, * \mathbb{C}}$, Joanna Pastwińska ${ }^{1,2}{ }^{2}$ Ewa Brzezińska-Błaszczyk ${ }^{1}$ and Justyna Agier ${ }^{1}$ (I) \\ 1 Department of Microbiology and Experimental Immunology, Faculty of Health Sciences, Medical University \\ of Lodz, Pomorska 251, 92-213 Lodz, Poland; joanna.pastwinska@stud.umed.lodz.pl (J.P.); \\ ewab@csk.umed.lodz.pl (E.B.-B.); justyna.agier@umed.lodz.pl (J.A.) \\ 2 Laboratory of Epigenetics, Institute of Medical Biology, Polish Academy of Sciences, Lodowa 106, \\ 93-232 Lodz, Poland \\ * Correspondence: paulina.zelechowska@umed.lodz.pl
}

Citation: Żelechowska, P.;

Pastwińska, J.; Brzezińska-Błaszczyk, E.; Agier, J. Do Mast Cells Contribute to the Antifungal Host Defense? Cells 2021, 10, 2510. https://doi.org/ $10.3390 /$ cells 10102510

Academic Editor: Cord Brakebusch

Received: 31 August 2021

Accepted: 20 September 2021

Published: 22 September 2021

Publisher's Note: MDPI stays neutral with regard to jurisdictional claims in published maps and institutional affiliations.

Copyright: (c) 2021 by the authors. Licensee MDPI, Basel, Switzerland. This article is an open access article distributed under the terms and conditions of the Creative Commons Attribution (CC BY) license (https:/ / creativecommons.org/licenses/by/ $4.0 /)$.

\begin{abstract}
The fungal kingdom includes a group of microorganisms that are widely distributed in the environment, and therefore the exposure to them is almost constant. Furthermore, fungal components of the microbiome, i.e., mycobiome, could serve as a reservoir of potentially opportunistic pathogens. Despite close encounters with fungi, defense mechanisms that develop during fungal infections remain unexplored. The strategic location of mast cells (MCs) close to the external environment places them among the first cells to encounter pathogens along with the other innate immune cells. MCs are directly involved in the host defense through the ability to destroy pathogens or indirectly by activating other immune cells. Most available data present MCs' involvement in antibacterial, antiviral, or antiparasitic defense mechanisms. However, less is known about their contribution in defense mechanisms against fungi. MCs may support immune responses to fungi or their specific molecules through initiated degranulation, synthesis and release of cytokines, chemokines, mediators, and generation of reactive oxygen species (ROS), as well as immune cells' recruitment, phagocytosis, or provision of extracellular DNA traps. This review summarizes current knowledge on host defense mechanisms against fungi and MCs' involvement in those processes. It also describes the effects of fungi or fungus-derived constituents on MCs' activity.
\end{abstract}

Keywords: mast cell; fungi; fungal infection; host defense; pathogen-associated molecular pattern

\section{Introduction}

The prevalence of fungal infections presents a global health issue and has been escalating in recent years. Due to the common multidrug resistance as well as lack of effective antifungal remedies, fungal infections have become increasingly difficult to treat. Moreover, in contrast to bacterial or viral infections, a successful vaccine against pathogenic fungi has not yet been developed [1,2]. Since fungi are ubiquitous in the environment, we are constantly and directly exposed to them on many levels. Furthermore, fungi form an integral part of the microbiome, which plays a role as a reservoir for opportunistic pathogens. The mycobiome maintains body homeostasis and influences the immunological responsiveness in the host organism. However, it has been reported that altered immune system function or mycobiome composition play an important role in several human diseases [3]. Despite the close encounters with fungi, the host defense mechanisms against various fungal pathogens are not fully known. One of the significant challenges is the unique structure of the fungi cell wall, which is the crucial element involved in the interaction with the host. In general, the fungal cell wall is a rigid structure composed of various types of linear and branched polysaccharides, glycoproteins, proteins, lipids, and other components. These components may be organized into at least two layers (Figure 1). The inner layer of most pathogenic fungi consists of a core of glycans, including chitin, which is located closest to the plasma membrane, and $\beta-1,3-$ and $\beta-1,6$-glucans adjacent to the chitin fibers. It has been indicated that $50-60 \%$ of the dry weight of this structure 
is made up of glucan with $\beta-1,3$-glycosidic linkages. Many fungi have an inner cell wall layer that also contains complex polymerized and/or indolic compounds called melanins. On the other hand, the composition of the outer layer may vary among fungal species, but generally, it is composed of $\alpha-1,3$-glucans or homopolymers of mannose, such as mannans and mannoproteins [4].

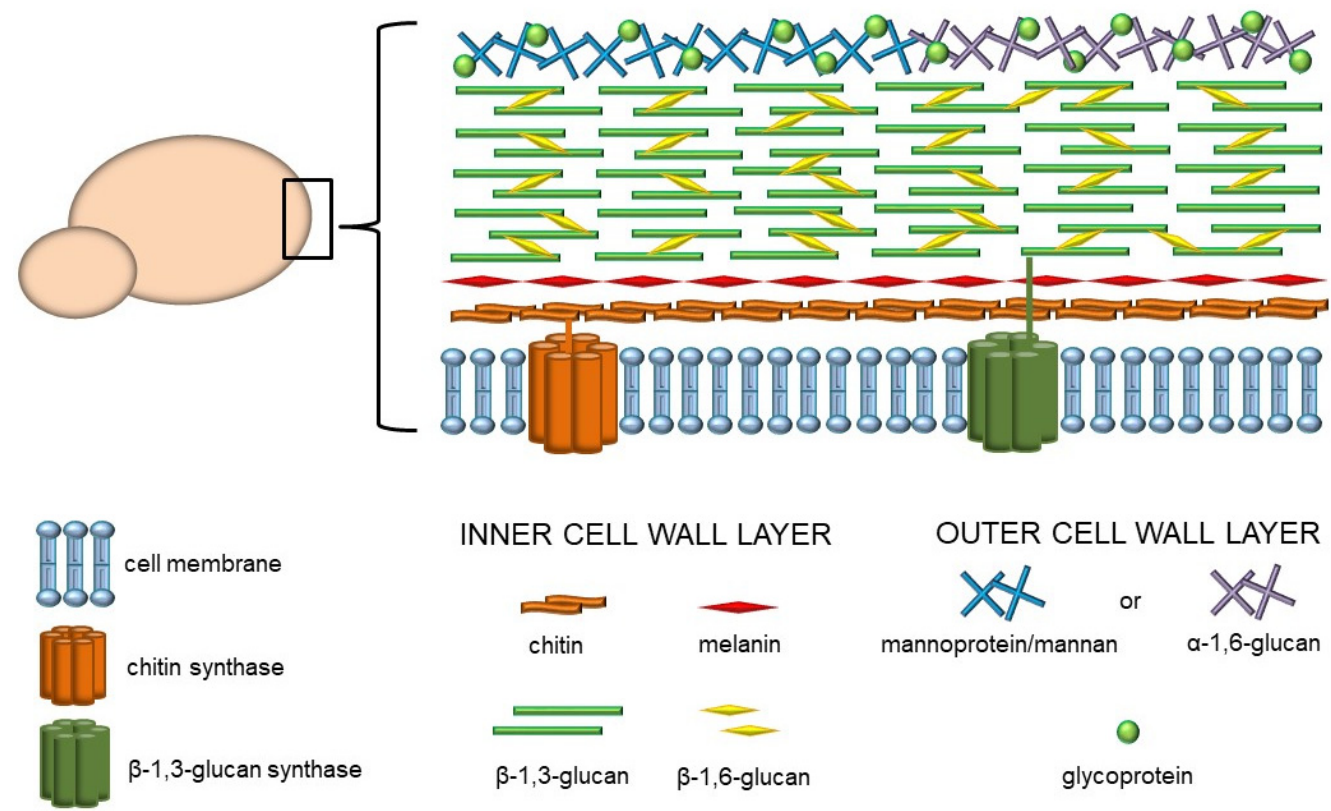

Figure 1. Structural organization and composition of the fungal cell wall.

Host defense against various pathogens, primarily bacteria and viruses, involves the orchestration of first-line innate immune responses and adaptive immunity mechanisms. The course of these processes depends to a large extent on the involvement of mast cells (MCs). However, no sufficient data have been found on MCs' contribution to defense against fungi. This review summarizes current knowledge of host defense mechanisms against fungi and $\mathrm{MCs}^{\prime}$ involvement in those processes. It also provides insight into the effects of fungi or specific fungus-derived constituents on MCs' activity.

\section{Microscopic Fungi and the Immune System}

Microscopic fungi and the substances they produce are quite common in the environment but also constitute the natural microbiota that colonizes the mucous membranes and the skin of living organisms, e.g., Candida spp. Under certain conditions, mainly due to tissue homeostasis disruption, infection with external pathogenic microorganisms and commensal species of fungi may occur. However, despite daily exposure to pathogens, a healthy organism usually resists all infections. This is due to the development of numerous sophisticated defense mechanisms, whose role is to recognize the threat and eliminate it $[5,6]$. The skin and mucous membranes overlining different surfaces in the body, e.g., in the respiratory system and gastrointestinal and genitourinary tracts, constitute a natural physical barrier limiting the penetration of microorganisms. Moreover, natural antimicrobial substances produced in the organism, such as $\beta$-defensins, cathelicidins, surfactant protein A (SP-A), SP-D, lysozyme, lactoferrin, and mucins $[5,7,8]$ as well as physiological microbiota provide a barrier that prevents the multiplication of foreign fungi [7]. In spite of a fungal pathogen defeating the physical barriers, further obstacles await it. These include the expression of various extra- and intracellular receptors specialized in pathogen recognition or secreted humoral factors [7,9].

Almost all types of immune cells are involved in antifungal defense, as each has different functions, complementing each other and creating an unbreakable network of interconnections. Among them, we can distinguish phagocytic cells such as neutrophils, 
monocytes and their tissue counterparts, and macrophages, but also dendritic cells (DCs), natural killer cells (NKs), B cells, various populations of T lymphocytes, or epithelial and endothelial cells. Numerous defensive substances are produced by these cells in order to combat the ongoing fungal infection, mostly indirectly through induction of chemotaxis and activation of other immune cells or by initiating various defense processes. Depending on the fungal etiological agent, they may play a major or minor role in recognizing and eliminating these pathogens. Monocytes infiltrate infected tissues and transform into macrophages which, apart from phagocytosing fungal pathogens, secrete inflammatory mediators to recruit and activate other immune cells, including neutrophils [6,7]. Macrophages particularly target the elimination of Cryptococcus spp. and Pneumocystis spp. Moreover, in the case of alveolar macrophages, they also target Aspergillus fumigatus. Despite coming from macrophages, neutrophils also play an essential role in the prevention of $C$. albicans and A. fumigatus. Therefore, neutropenia strongly predisposes to, e.g., Candida infections. In addition, neutrophils regulate the generation of reactive oxygen species' (ROS) as well as use non-oxidative mechanisms in fungus elimination. Hence, they are responsible for the release of antimicrobial substances, such as $\beta$-defensins, lysozyme, lactoferrin, elastase, gelatinases, and cathepsin G. For example, elastase regulates the formation of neutrophil extracellular traps (NETs) composed of neutrophil DNA, especially useful in immobilization and neutralization of fungal hyphae due to their size, which prevents phagocytosis $[6,7,10]$. On the other hand, dendritic cells, after contact with Candida spp., release interferon (IFN)- $\beta$ in spleen tyrosine kinase (SYK)-dependent and IFN regulatory factor 5 (IRF5)-dependent pathways, apart from phagocytosis and presentation of antigens. Further presentation of antigens leads to the activation of T helper (Th) cells, e.g., Th17, which, through the production of IL-17 and IL-22, contribute to the recruitment of neutrophils as well as enhance the release of $\beta$-defensins by epithelial cells. In addition, Th17 cells, through the production of IL-17A, appear to play a vital role in the immune response against C. albicans $[6,7,11]$. $\mathrm{CD}^{+}$and $\mathrm{CD}^{+} \mathrm{T}$ cells, including $\mathrm{Th} 1$, are also involved in response to fungal infection, specifically to Cryptococcus neoformans in the central nervous system (CNS). It is suggested that Th2 cells may be involved in infections with dermatophytes, such as Trichophyton rubrum, due to the presence of IgE and IgG4 antigens of T. rubrum in the serum. As a result, the cytokines IL-4, IL-5, and IL-10 are produced [12]. Often underestimated in immune defense, platelets are also involved in the anti-Candida response by stimulating the synthesis of antifungal CCL5 and platelet factor 4 (PF4). Antibodies, whose role is to opsonize fungi, prevent their adhesion, or neutralize toxins, are a unique product of B cells [6,7].

Before the immune system can fight the pathogen, it must first recognize the threat in order to send the best-adapted units to the rescue. To this end, pattern recognition receptors (PRRs) serve as signaling proteins that can recognize microbial-associated molecular patterns (MAMPs) specific for various microorganisms and damage-associated molecular patterns (DAMPs), which are released by damaged cells or tissues of the host. Among them, we can distinguish Toll-like receptors (TLRs), C-type lectin receptors (CLRs), NOD-like receptors (NLRs), and RIG-I-like receptors (RLRs) [5,6,9,10,13]. Some of the more important TLRs are TLR2 and TLR4, which are stimulated by Candida spp. and Aspergillus spp. Surface substances present on these fungi, such as zymosan, phospholipomannan, and glucuronoxylomannan (GXM) stimulate TLR2. In contrast, GXM and O-linked mannan are the most common ligands for TLR4 $[5,6,9]$. It is notable that the signaling pathway induced by TLR4 leads to the generation of a more vigorous response associated with the activity of pro-inflammatory Th1 cells than in the case of TLR2 connected to the predominance of anti-inflammatory Th2 cells and regulatory T cells (Treg) $[9,10]$. Other important TLRs are TLR3 (with double-stranded RNA from conidia as a ligand) inducing IFN- $\gamma$ production, TLR6 (with zymosan as a ligand) regulating IL-17 and IL-23 production, and TLR9 recognizing chitin and unmethylated CpG motifs from fungal DNA [5,6,9,10,13]. Dectin-1, a known CLR, can bind $\beta$-glucans (including zymosan) present in the cell walls of, e.g., Candida spp. and Aspergillus spp. [5,6,9,10,13-15]. It also has a function in regulating the for- 
mation of NETs, mainly to prevent their uncontrolled formation $[6,10,15]$. Moreover, TLR2 and Dectin-1 collaboration leads to increased stimulation of the immune system by the release of the pro-inflammatory cytokines. Activation of these receptors may also signal the immune cells to begin phagocytosis $[5,6,9,13]$. Another CLR is the mannose receptor (MR), which, apart from mannans and mannoproteins, also recognize the glycoprotein A (gpA) complex $[5,6,9,10,14,15]$. Specifically, macrophage MR can identify Candida auris mannoproteins, which stimulate immune response more than C. albicans [6,15]. Dectin-2 and Dectin-3, boosted by Candida glabrata $\alpha$-mannan and DC-specific intercellular adhesion molecule3-grabbing non-integrin (DC-SIGN), as well as macrophage-inducible $\mathrm{Ca}^{2+}$-dependent lectin receptor (Mincle), all responsive to C. albicans infection and the presence of mannans and mannoproteins, also belong to the CLR family. Mincle activation is associated with tumor necrosis factor (TNF) production, while DC-SIGN regulates Th cell activation and differentiation $[5,6,9,14,15]$. TLR and CLR signaling pathways are often involved in signal transduction by the CARD9 adapter protein, a crucial component of NFKB and Syk pathways, leading to the secretion of TNF, IL-1 $\beta$, IL-6, IL-12, and granulocyte-macrophage colony-stimulating factor (GM-CSF). Lack of CARD9 predisposes the body to increased fungal infections $[6,14]$. MyD88 is also exemplified as a molecule in the TLR signaling pathway that plays a vital role in maintaining fungal infections $[6,10,13,14]$. Slightly less is known about the contribution of NLRs and RLRs to the antifungal response. However, from the available data, it can be concluded that melanoma differentiation-associated protein 5 (MDA5), a receptor belonging to the RLR family, recognizes Candida spp. RNA. As for NLRs, there are known representatives of NOD1 and NOD2, which activate the NFKB pathway through receptor-interacting protein 2 (RIP2). Chitin is a well-known ligand for NOD2. Moreover, within this family, proteins such as NLRP1-14 are known to form complexes called inflammasomes. There are indications that $A$. fumigatus can activate the formation of these complexes, which leads to the formation of active forms of IL-1 $\beta$ and IL-18 from inactive precursors [5,6,9,10,13-15].

Just as the immune system has successfully adapted to kill microbes, pathogens have developed mechanisms that enable them to survive, making these strategies no less critical than virulence factors. These processes include the production of immunesuppressing particles, shielding of stimulatory MAMPs, adapting the composition and organization of the cell wall, biofilm formation, inducing an anti-inflammatory response rather than a pro-inflammatory, or dimorphic capacity $[9,16]$. Many fungi, including Metarhizium anisopliae, can produce toxic peptides, i.e., destruxins, that suppress the production of antimicrobial peptides in Drosophila melanogaster, which is a model for human immune responses in the transduction of key signals [17]. Candida spp., in response to the prevention of adhesion to the skin, developed adhesins, proteins related to $\beta$ glucan that also enable the formation of biofilms. Some fungi, including C. albicans, can change their phenotype, thanks to which they can hide the molecules detected by PRRs, such as $\beta$-glucan. Another way to hide MAMPs is to get rid of them, as in the case of Coccidioides posadasii, which uses a secreted metalloproteinase to digest spherule outer wall glycoprotein (SOWgp). Pneumocystis spp. developed a mechanism involving the release of gpA that blocks MR, thus protecting the pathogen from opsonization. Pathogenic fungi, such as C. albicans and C. neoformans, modulate the immune response in the antiinflammatory direction, mainly by TLR2 stimulation and subsequent Th2 recruitment. An equally clever way to avoid phagocytosis is the ability to enter host cells such as epithelial and endothelial cells, as in the case of C. albicans, A. fumigatus, and C. neoformans $[9,16]$.

\section{How Do MCs Contribute to the Host Defense?}

MCs play a pivotal role in the host defense against pathogenic microorganisms for several reasons. First of all, MCs' strategic position at the host-external environment interfaces, i.e., in the subepithelial layers of the skin, the respiratory system, or in the gastrointestinal and genitourinary tracts, means that they are among the first cell population to interact with invading microbes along with other innate immune cells, such as epithelial 
cells, and trigger a response against them. Moreover, it is well known that MCs may initiate and combat the clearance of pathogens by several mechanisms of action [18-20]. MCs possess an array of bioactive substances, which affect all stages of inflammation during infection, including its initiation, maintenance, and even resolution. They include granule-associated preformed mediators (e.g., histamine, tryptase, chymase, carboxypeptidases, metalloproteinases, proteoglycans), de novo-produced eicosanoid metabolites (e.g., leukotrienes (LTs), prostaglandins, thromboxanes), as well as many newly synthesized cytokines/chemokines [21-25]. MC activity against pathogens also involves the release of some antimicrobial peptides and the production of ROS. Moreover, these cells can engulf invading microbes via phagocytosis and kill them through oxidative and non-oxidative systems [18,19]. Another described strategy used by MCs to destroy microorganisms is through extracellular traps (MCETs) composed of DNA, histones, and granule proteins [26]. The relevance of MCETs has been documented in antibacterial, antifungal, or antiparasitic host defense [27,28]. Following phagocytosis, MCs may process pathogen antigens for presentation through class I and II MHC molecules, which leads to the development of adaptive antimicrobial immunity [29]. As MCs express PRRs, they may act as effectors of host defense through their ability to detect various MAMPs or endogenous DAMPs released in response to infection. The available data indicate that among PRRs expressed on MCs, there are representatives from TLRs, RLRs, and NLRs, as well as CLRs [30]. It has been reported that MCs can recognize bacterium-associated molecules, such as lipopolysaccharide (LPS), lipoteichoic acid (LTA), or peptidoglycan (PGN) mainly through TLRs but also via some NLRs. In turn, specific TLRs and RLRs are involved in MC response to viral dsRNA, ssRNA, or envelope proteins. Among PRRs expressed on MCs, there are also molecules from the CLR group or some TLRs, which may sense different fungal components (Figure 2) [30]. However, little information exists concerning MC involvement in antifungal host defense, and the function of MCs in fungal infections is not precisely defined [31,32].
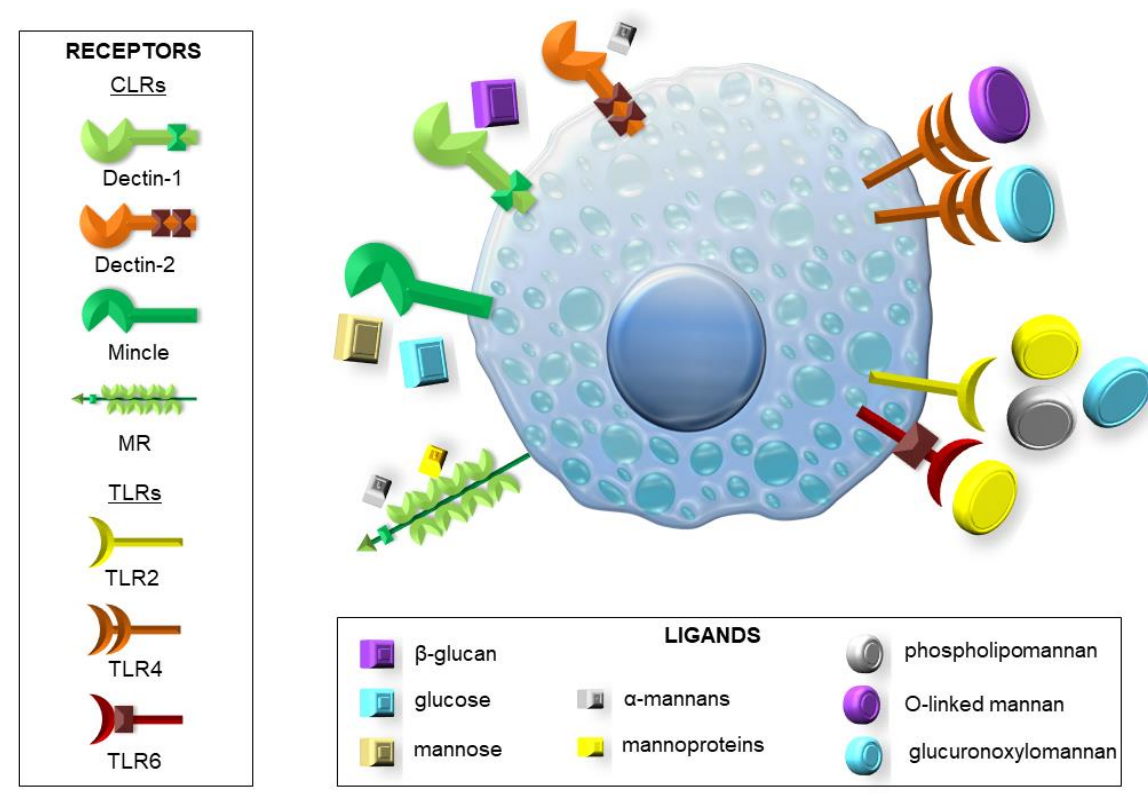

Figure 2. Expression of PRRs involved in sensing different fungal components on MCs.

\section{Expression of PRRs Involved in Fungus Recognition in MCs}

It is well known that CLR family members are strongly involved in recognizing fungi and their components [33]. However, data showing the expression of these receptors within MCs are still limited. Among investigated receptors from the CLR group, the most presented reports concerned Dectin-1 primarily. Only a handful of studies revealed the expression of Dectin-2, MR, or Mincle within MCs, whereas Dectin-3's presence on these cells 
has not been investigated yet. The constitutive expression of Dectin- 1 has been confirmed in bone marrow-derived MCs (BMMCs) [34], cord blood-derived MCs (CBMCs) [35], a human leukemic cell line (KU-812) that displays enhanced tryptase expression [35], the rat basophilic leukemia clone $2 \mathrm{H} 3$ cell line (RBL-2H3), i.e., mucosal-like MCs [36], and tryptase-positive progenitor-derived MCs [37], both at mRNA and protein levels. We have recently documented that rat connective tissue type MCs, i.e., peritoneal MCs (PMCs), also constitutively express Dectin-1 and Dectin-2 mRNA and protein [38,39]. To date, the expression of mRNA and protein of Mincle has been demonstrated only in RBL-2H3 cells [40] and tryptase-positive progenitor-derived MCs [37]. The protein expression of MR was documented in murine BMMCs and PMCs [41].

Expression of all known members from the TLR family has been confirmed in a wide range of MC types and cell lines. However, as mentioned earlier, it has been established that only certain TLRs participate in fungus sensing. Among them, the most important for fungus detection seems to be TLR4. The mRNA or protein expression of TLR4 was documented in a mouse MC line (MC /9) [42], in MC lines that closely resemble primary human MCs, i.e., a human MC line (HMC-1) and Laboratory of Allergic Diseases 2 (LAD2) cells [43], murine BMMCs [44], murine fetal skin-derived cultured MCs (FSMCs) that exhibit important features of connective tissue type MCs [44], and CBMCs [45], as well as rat and murine PMCs [44,46]. TLR2 is another well-characterized PRR participating in fungus recognition. Available data indicate that mRNA and/or protein expression of TLR2 are found in MC/9 [42], HMC-1 and LAD2 cells [43,47], murine BMMCs and FSMCs [44,48], CBMCs [45], and in mature rat PMCs [46]. Since TLR2 forms heterodimers with TLR6 to recognize fungal components, it should be stressed that its expression has also been documented on different MC types, including MC/9 [42], HMC-1, LAD2 cells [49], human cultured MCs (HCMCs) [49], FSMCs and BMMCs [44], CBMCs [45], and rat PMCs [46].

An interesting observation is that fungi or fungus-derived constituents may modulate the expression of some PRRs in MCs. Ribbing et al. [37] documented that the stimulation of tryptase-positive progenitor-derived MCs with Malasezzia sympodialis extract or after IgE receptor cross-linking resulted in an increased expression of Mincle mRNA. Saccharomyces cerevisiae-derived zymosan, i.e., $\beta$-1,3-glucan containing mannan particles, significantly upregulates surface expression of the Dectin-1 receptor in murine BMMCs [34]. Only a few reports exist regarding the effect of various endogenous factors on PRRs involved in fungus recognition in MCs. Our observations provided evidence that IL-6 treatment of PMCs induces an increase in TLR4 expression, whereas exposure of those cells to CCL5 results in decreased expression of both TLR2 and TLR4 [50]. Okumura et al. [51] found that IFN- $\gamma$ upregulates TLR4 expression on human peripheral blood-derived MCs and Yang et al. [52] demonstrated that IL-12 induces a significant increase in the expression of TLR2 and TLR4 mRNAs and proteins in the P815 cell line. Our recent data have revealed that one of the well-known antimicrobial peptides, i.e., cathelicidin LL-37, increases TLR2 and TLR4 expression in the PMCs [53]. Similar observations were made by Yoshioka and colleagues [54] as they observed augmented TLR4 expression in LAD2 cells in response to LL-37.

\section{Fungi Affect MC Activity}

\subsection{Effect of Fungal Cells on MCs}

Evidence indicates that fungi directly induce MC activity in vitro, and most of the available data concern their effect on the generation and/or release of different mediators from MCs (Table 1). It has been documented that some species of fungi stimulate MCs to release preformed mediators. They also promote the production of a variety of factors, cytokines, and chemokines, including those which are known for their potent inflammatory and antifungal activities. Yeasts, hyphae, and the cell wall fraction of $C$. albicans activate murine BMMCs, HMC-1, and RBL-2H3 cells as well as rat PMCs, thus resulting in degranulation and $\beta$-hexosaminidase release [55-57]. Additionally, Nieto-Patlán and co-workers [55] evaluated BMMC degranulation by the exposure of CD107a on the cell sur- 
face after MC activation. They reported that the percentage of BMMCs positive for CD107a increases after stimulation with $C$. albicans hyphae or yeasts compared to non-stimulated cells [55].

Table 1. The influence of fungi or their cells on MC mediator synthesis.

\begin{tabular}{|c|c|c|c|}
\hline Fungi & MC Types & Mediators & References \\
\hline Aspergillus fumigatus (mature hyphae) & RBL-2H3 & $\begin{array}{c}\text { histamine, } \\
\beta \text {-hexosaminidase }\end{array}$ & [58] \\
\hline Candida albicans & HMC-1 & IL-1Ra, IL-16, MIF, CXCL8 & [57] \\
\hline Candida albicans (hyphae) & SMCs & TGF- $\beta$ and IL-10 & [59] \\
\hline Candida albicans (yeasts) & BMMCs & IL- $1 \beta$ & [55] \\
\hline Candida albicans (hyphae, yeasts) & BMMCs & $\begin{array}{l}\text { TNF, IL-6, IL-10, } \\
\text { IL-13, CCL3, CCL4 }\end{array}$ & {$[55,60]$} \\
\hline Candida albicans (cell wall, hyphae, yeasts) & $\begin{array}{c}\text { BMMCs, HMC-1, PMCs, } \\
\text { RBL-2H3 }\end{array}$ & $\begin{array}{c}\text { histamine, } \\
\beta \text {-hexosaminidase }\end{array}$ & [55-57] \\
\hline Cryptococcus neoformans & CBMCs, HMC-1 & $\beta$-hexosaminidase, tryptase & [61] \\
\hline Malasezzia sympodialis & $\begin{array}{c}\text { BMMCs, PMCs } \\
\text { IgE-sensitized BMMCs } \\
\text { PBMCs }\end{array}$ & $\begin{array}{c}\text { cysLTs, TNF, IL-6 } \\
\text { histamine, cysLTs, CCL2 } \\
\text { IL-6 }\end{array}$ & {$[37,62]$} \\
\hline Paracoccidioides brasiliensis & RBL-2H3 & $\begin{array}{c}\text { histamine, } \\
\beta \text {-hexosaminidase }\end{array}$ & [63] \\
\hline Sporothrix schenckii & BMMCs, PMCs & cysLTs, TNF, IL-6 & [64-66] \\
\hline
\end{tabular}

BMMCs, bone marrow-derived MCs; CBMCs, cord blood-derived MCs; HMC-1, human MC line; PBMCs, peripheral blood MCs; PMCs, peritoneal MCs; SMCs, stromal MCs; RBL-2H3, rat basophilic leukemia clone 2H3.

Paracoccidioides brasiliensis cells and mature A. fumigatus hyphae, but not conidia or immature hyphae, also induce RBL-2H3 cell degranulation and $\beta$-hexosaminidase secretion $[58,63]$. Moreover, $C$. neoformans cells trigger CBMCs and HMC-1 to release $\beta$-hexosaminidase and tryptase [61]. Conversely, treatment of murine BMMCs with M. sympodialis extract as well as incubation of those cells and rat PMCs with conidia or cells of Sporothrix schenckii yeast does not induce MC degranulation [62,64,65]. BMMCs do not degranulate in response to $S$. schenckii as assessed by $\beta$-hexosaminidase release and CD63 surface expression by flow cytometry [66]. Such ambiguous observations suggest that conventional MC degranulation may not be a prerequisite for preformed MC mediators to exert a protective effect during fungal infections. It was also observed that M. sympodialis or S. schenckii activate BMMCs and/or rat connective tissue type PMCs to release robust pro-inflammatory mediators, i.e., cysteinyl LTs (cysLTs) and cytokines, including TNF and IL-6 [62,64,66]. M. sympodialis extract enhances the release of cysLTs from IgE-sensitized BMMCs and induces their degranulation and CCL2 production [62]. It was also noted that peripheral blood MCs obtained from atopic eczema patients release increased amounts of IL-6 in response to M. sympodialis [37]. This report suggests that MC-derived de novo-synthesized cytokines may contribute to the skin inflammation in atopic eczema during fungal infection. Interestingly, it has been indicated that MC tryptase may serve as a potential biomarker of the A. fumigatus-host interaction since production of this protease is decreased in patients displaying specific IgE to A. fumigatus compared to patients without detectable IgE to this fungus [67]. It is well known that MCs play a vital role in extracellular matrix remodeling/degradation through the release of preformed enzymes, such as tryptase, chymase, or carboxypeptidases. MC-derived proteases improve fibroblast and epithelial cell proliferation and leukocyte recruitment. They also induce angiogenesis as well as collagen synthesis in damaged tissue [20]. Therefore, it may be suggested that in a specific tissue microenvironment, i.e., in the site of pathogen contact, MCs promote wound healing or fibrotic events [68]. Both yeasts and hyphae of $C$. albicans stimulate murine BMMCs to synthesize pro-inflammatory cytokines, including TNF, IL-6, IL-13, chemokines CCL3, and CCL4, but also anti-inflammatory IL-10 [55,60]. Moreover, 
only yeasts of $C$. albicans activate BMMCs to produce and release IL-1 $\beta$, which exerts potent pro-inflammatory activity [55]. Upon C. albicans stimulation, HMC-1 cells secrete interleukin-1 receptor antagonist (IL-1Ra), IL-16, and migration inhibitory factor (MIF) [57]. Renga et al. [59] reported that stromal MCs produce higher concentrations of transforming growth factor $\beta$ (TGF- $\beta$ ) and IL-10 than mucosal MCs in response to hyphae of $C$. albicans. The authors suggest that $C$. albicans exploits MC functional versatility at mucosal surfaces to contribute to local damage and inflammation or protection [59]. Interestingly, HMC-1 cells infected with C. albicans secrete significant amounts of CXCL8 [57], a chemokine possessing a solid chemotactic activity for neutrophils. Of note, another opportunistic pathogen, Pneumocystis jirovecii, is an atypical fungus with lung tropism that causes pneumonia in immunosuppressed individuals, such as HIV infection. Based on the available data, it can be speculated that MCs modulate the duration of opportunistic fungal infections through the release of the mediators. It has been reported that $P$. jirovecii-infected patients present high expression levels of IL-2, IL-4, IL-10, and IL-13 compared to healthy subjects [69]. It is worth noting that MCs are an important source of these multifunctional cytokines. Interestingly, an increased prevalence of $P$. jirovecii colonization has also been observed in patients with chronic obstructive pulmonary disease, in which MCs seem to be involved [70].

Additionally, it has been established that supernatants from C. albicans-infected HMC1 cells induce migration of neutrophils but not monocytes, supporting the critical role of this chemokine in neutrophil recruitment towards C. albicans [57]. In contrast, stimulation with supernatants from $C$. neoformans-infected CBMCs and HMC-1 cells induces migration of macrophages but not neutrophils [61]. It has also been reported that murine BMMCs infected with C. albicans augment macrophage crawling ability and promote their chemotaxis [60].

It is worth noting that MCs accumulate in the tumor stroma of a wide range of cancer types. Therefore, the evidence for the role of these cells in shaping cancer and its microenvironment continues to grow [71,72]. Data indicate that fungi are implicated in oncogenesis and the ability to induce inflammation, which may cause cancer. For example, evidence suggests that $C$. albicans infection may be associated with oral cancer development [73]. Bearing in mind an increased MC infiltration into the tumor microenvironment and that MCs are involved in fungal infections, it can be stated that these cells may mediate the development of a tumor or tumors by altering the inflammatory environment. As mentioned earlier, MCs remodel the extracellular matrix during wound healing/tissue repair, but it should be stressed that this function is subverted in tumor growth [20]. Considering that MCs produce pro-fibrotic mediators, such as TGF- $\beta$, in response to some fungi or their specific constituents [59], it can also be hypothesized that MCs may contribute to fibrotic lesions during fungal infections.

The available data regarding the mechanisms of direct killing strategies of fungi exerted by MCs are unclear. A few authors indicate that these cells primarily combat the fungi through extracellular mechanisms, whereas others describe their phagocytic capabilities. Indeed, Trevisan et al. [74] reported that rat PMCs have limited capacity to phagocytose C. albicans. However, it has been strongly suggested that these cells are able to kill yeasts in the extracellular environment, probably through the fungicidal activity of secreted mediators, including ROS and the enzyme $\beta$-hexosaminidase. These observations were confirmed in in vivo studies and in situ findings. Yan et al. [75] created a rat model of acute invasive fungal rhinosinusitis (AIFR) based on A. fumigatus infection. The authors revealed that MCs might mainly play a role through degranulation, or the release of cytokines/chemokines involved in immune response instead of direct phagocytosis of fungi during AIFR. They observed that compared to control rats, the total number of MCs is unchanged, but MC degranulation is only found in the infected nasal cavities of AIFR rats [75]. The notion that MCs play a protecting role in fungal infection through their degranulation was also supported by the findings of Xie and co-workers [76]. Histological staining revealed a larger number of degranulated/total MCs in the corneal limbus in a mouse model of Fusarium spp. keratitis as compared to normal mice, which results in vasodilation, 
increased intercellular adhesion molecule-1 (ICAM-1) expression on endothelial cells, and neutrophil infiltration [76]. Furthermore, a significant increase in the number of MCs in the dermis and subcutaneous tissue of rats after inoculation with the metabolic extract of Fusarium oxysporum compared to the animals from the control group was documented [77]. In contrast, MCs did not reveal signs of degranulation in response to S. schenckii in situ, as assessed by quantitative histomorphometric analysis of infected skin sites of mice [66]. Another important finding noted by Xie et al. [76] was that stabilization of MCs with cromolyn leads to inhibition of MC degranulation, dramatic suppression of vascular dilation/permeability, lower ICAM-1 expression, and markedly reduced neutrophil infiltration, which results in increased fungal growth and higher corneal perforation [76]. To the best of our knowledge, no other studies exist that adequately cover MC stabilization during fungal infection. Therefore, future studies investigating the potential of anti-Siglec- 8 or anti-FceRI therapies in fungal infections would be very interesting to provide new information from a clinical point of view.

Noteworthily, Lopes et al. [57] showed that HMC-1 cells and CBMCs release extracellular structures upon $C$. albicans stimulation. These structures are MCETs, which ensnare pathogens. Additionally, the same authors demonstrated that C. albicans yeasts could be internalized by MCs, where they can grow and germinate, leading to disruption of MC membranes and ultimately promoting cell death [57]. MCs also modulate the phagocytic activity of resident macrophages during fungal infections as it has been indicated that uninfected BMMCs inhibit phagocytosis of $C$. albicans by macrophages [60]. In contrast, Pinke et al. [78] reported the ability of murine BMMCs to phagocytose $C$. albicans and produce NO with meaningful participation of both Dectin-1 and TLR2 receptors in this process. It has been also demonstrated that HMC-1 cells are not able to phagocytose capsulated C. neoformans. However, in the case of the acapsular mutant strain of this pathogenic fungus, a higher rate of HMC-1 cell phagocytosis and survival of those cells was observed [61].

\subsection{Effect of Fungus-Derived Molecules on MCs}

More detailed studies show that several different fungal components, predominantly derived from the fungal cell wall or fungal metabolites, directly affect MC activity. The first report demonstrating the influence of specific fungal molecules on MCs was presented by Padawer and Fruhman as early as 1968 [79]. By electron microscopy, they observed the phagocytosis of zymosan particles by rat PMCs. Later, an investigation on the effect of fungal molecules on MCs was presented by Nosál and co-workers in 1974 [80]. They found that glycoprotein, a polymeric compound isolated from the strain of $C$. albicans CCY 29-3-109, activates rat MC from peritoneal and pleural cavities to degranulate, as was assessed by histamine release [80]. Several further studies also examined the effect of fungus-derived molecules to initiate MC degranulation. However, similarly to studies with specific fungal species, the results in this context are ambiguous. It was demonstrated that mannan and $\beta$-glucan obtained from the $C$. albicans fungal cell wall induce RBL-2H3 cell degranulation and $\beta$-hexosaminidase secretion [56]. Interestingly, Aspergillus oryzaederived lectin induces the secretion of $\beta$-hexosaminidase from RBL-2H3 sensitized with IgE [81]. Furthermore, mannan and/or zymosan from $S$. cerevisiae stimulates rat PMCs but not CBMCs to degranulate [82-84]. In turn, $\beta$-glucan derived from Aureobasidium pullulans inhibits the degranulation of both RBL-2H3 and BMMCs without causing cytotoxicity towards these cells [85]. Gliotoxin, i.e., metabolite released by pathogenic fungi, also suppresses both FceRI-dependent and -independent BMMC and RBL-2H3 cell degranulation [86]. Additionally, we and other authors indicated that curdlan, a purified linear 3-1,3-glucan produced by the bacterium Alcaligensis faecalis and widely used as a model fungal particle, induces PMCs and BMMCs to degranulate as well as histamine and/or $\beta$-hexosaminidase release [38,87].

Extensive data show that de novo synthesis of many MC mediators is augmented in response to the fungal cell wall molecules. Our recent findings revealed that mannan derived from $S$. cerevisiae activates rat PMCs to generate potent pro-inflammatory medi- 
ators, including cysLTs, TNF, CCL2, and CCL3, as well as immunoregulatory IFN- $\gamma$ and GM-CSF [82]. In turn, stimulation with zymosan results in an increase of IL-33 mRNA expression [88] as well as $\mathrm{LTB}_{4}, \mathrm{LTC}_{4}, \mathrm{IL}-1 \beta$, and GM-CSF synthesis by CBMCs $[35,84]$. Moreover, our paper reported that PMCs release cysLTs, IFNs, GM-CSF, TNF, and CCL2 in response to zymosan [83]. It has also been demonstrated that PbPga1 protein, a surface antigen of $P$. brasiliensis yeast, induces IL-6 release from RBL-2H3 cells [63]. Curdlan also affects the generation of various mediators from MCs. Kimura et al. [36] documented that this molecule induces mRNA expression of IL-3, IL-4, IL-13, TNF, and CCL2 in RBL-2H3 cells. In turn, we have shown that curdlan activates rat PMCs to synthesize cysLTs, TNF, IFN- $\alpha$, IFN- $\gamma$ CCL3, and GM-CSF [38]. Conversely, a fungal metabolite, i.e., gliotoxin, suppresses $\mathrm{LTC}_{4}, \mathrm{IL}-13$, and TNF release from RBL-2H3 cells [86]. The summary of the influence of fungus-derived molecules on MC mediator synthesis is presented in Table 2.

Table 2. The influence of fungus-derived molecules on MC mediator synthesis.

\begin{tabular}{|c|c|c|c|}
\hline Fungus-Derived Molecules & MC Types & Mediators & References \\
\hline $\begin{array}{c}\text { curdlan } \\
\text { (Alcaligensis faecalis) }\end{array}$ & $\begin{array}{l}\text { PMCs } \\
\text { BMMCs }\end{array}$ & $\begin{array}{c}\text { histamine, cysLTs, TNF, IFN- } \alpha \text {, IFN- } \gamma \\
\text { CCL3, } \\
\text { GM-CSF, ROS } \\
\text { histamine, } \\
\beta \text {-hexosaminidase }\end{array}$ & {$[38,87]$} \\
\hline $\begin{array}{c}\text { glycoprotein } \\
\text { (Candida albicans) }\end{array}$ & PMCs & histamine & {$[80]$} \\
\hline lectin (Aspergillus oryzae) & IgE-sensitized RBL-2H3 & $\beta$-hexosaminidase & [81] \\
\hline $\begin{array}{c}\text { mannan } \\
\text { (Candida albicans) } \\
\text { mannan } \\
\text { (Saccharomyces cerevisiae) }\end{array}$ & $\begin{array}{l}\text { RBL-2H3 } \\
\text { PMCs }\end{array}$ & $\begin{array}{c}\text { histamine, } \\
\beta \text {-hexosaminidase } \\
\text { histamine, cysLTs, TNF, CCL2, CCL3, } \\
\text { IFN- } \gamma \text {, GM-CSF, ROS }\end{array}$ & {$[56,82-84]$} \\
\hline $\begin{array}{c}\text { PbPga1 } \\
\text { (Paracoccidioides brasiliensis) }\end{array}$ & RBL-2H3 & IL-6 & [63] \\
\hline $\begin{array}{c}\text { zymosan } \\
\text { (Saccharomyces cerevisiae) }\end{array}$ & $\begin{array}{l}\text { BMMCs } \\
\text { CBMCs } \\
\text { PMCs }\end{array}$ & $\begin{array}{c}\text { ROS, NO } \\
\text { LTB }_{4}, \text { LTC }_{4}, \text { IL-1 } \beta, \text { GM-CSF } \\
\text { histamine, cysLTs, TNF, IFNs, } \\
\text { GM-CSF, CCL2, ROS }\end{array}$ & {$[35,82-84,88]$} \\
\hline $\begin{array}{c}\beta \text {-glucan } \\
\text { (Candida albicans) }\end{array}$ & RBL-2H3 & $\begin{array}{c}\text { histamine, } \\
\beta \text {-hexosaminidase }\end{array}$ & [56] \\
\hline
\end{tabular}

BMMCs, bone marrow-derived MCs; CBMCs, cord blood-derived MCs; PMCs, peritoneal MCs; RBL-2H3, rat basophilic leukemia clone $2 \mathrm{H} 3$.

Considering that ROS are highly toxic to microorganisms, including pathogenic fungi, the information that MCs generate free radicals in response to fungus-derived constituents is highly relevant. It has been established that zymosan from S. cerevisiae stimulated ROS and NO generation by murine BMMCs [34,78]. We have recently documented that zymosan and mannan, as well as curdlan, also promote ROS generation by rat PMCs $[38,82,83]$.

Some fungus-associated molecules promote MC chemotactic activity. $\beta$-glucans, including zymosan and curdlan, as well as mannan, serve as potent chemoattractants for rat PMCs. Recently, we have shown that these molecules cause migration of rat PMCs, even in the absence of extracellular matrix (ECM) proteins $[38,82,83]$. It can be therefore stated that MCs accumulate in large numbers at the site of fungal infection. In turn, the accumulation of MCs at the inflamed milieu leads to further exacerbation and amplification of the ongoing inflammatory process.

\section{MCs and Th17 Cells}

MCs may play an essential role in the functions of Th17 lymphocytes, a cell subset that has an influential role in bridging the adaptive and the innate immune response against pathogenic fungi. It should be noted that Th17 cells constitute a source of IL-22 
and IL-17, which are essential cytokines for the successful antifungal response [89,90]. Although there is no direct evidence that MCs interact with Th17 cells in host defense mechanisms against fungi, growing evidence demonstrates that MCs are important for Th17 cell differentiation. Therefore, information that stimulation of T cells with supernatant of activated MCs increases the number of IL-17-producing T lymphocytes seems highly relevant [91]. It has also been observed that MC-derived TNF is required to develop IL17-secreting Th17 cells in a murine model of airway inflammation [92]. IL-33-stimulated MCs also induced Th17 differentiation in eosinophil-deficient mice, leading to neutrophildominant airway inflammation [93]. Interestingly, Th17 cells express functional histamine $\mathrm{H} 4$ receptor; thus, $\mathrm{MC}$-derived histamine may affect Th17 activity [94]. Indeed, stimulation with histamine or an $\mathrm{H} 4$ receptor agonist increases the production of IL-17 by human Th17 cells [94]. Considering that cysLTs and chemokine CCL2 act as chemoattractants for Th17 cells, and MCs are a source of these mediators, it can be assumed that MCs may regulate Th17 infiltration [95,96]. MCs can also promote T cell response in the host defense by modifying the functions of antigen-presenting cells. It has been shown that murine PMCs can undergo an interaction with immature DCs, inducing DC maturation and the release of the T cell-modulating cytokines IFN- $\gamma$, IL-2, IL-6, and TGF- $\beta$. Such MC-primed DCs subsequently induced T cell proliferation and Th1 and Th17 responses [97]. On the other hand, Th17 lymphocytes may also influence MCs activity. Cho et al. [98] reported that the Th17-mediated inflammatory environment promotes MC accumulation and survival through keratinocyte-derived stem cell factor (SCF).

\section{Concluding Remarks}

The currently available data regarding MC involvement in the antifungal host defense are ambiguous, primarily because studies have been carried out on MC types that display various characteristics and express a different array of PRRs. On the other hand, most of the investigations have been conducted with several fungal species that differ in the cell wall structure. Moreover, studies in this field concern whole fungal cells or their specific molecules. Without a doubt, this research area still requires exploration, and it is not yet possible to make definitive statements about the role of MCs in defense mechanisms developing in the course of fungal infection. However, based on the presented facts, it can be assumed that these cells are undoubtedly crucial for initiating a protective inflammatory response to fungal pathogens or their components (Figure 3). To this end, MCs release robust pro-inflammatory mediators, such as histamine and cysLTs, which affect vascular permeability or cell adhesion to the vascular epithelium, enhance phagocyte activity, and generate other factors with pro-inflammatory activities. Moreover, MCs synthesize specific cytokines and chemokines, including those engaged in defense against fungi. They are responsible for activating other immune cells, e.g., fungus-stimulated MCs release CXCL8 accountable for neutrophil recruitment. It should be stressed once again that MCs may contribute to the protection against fungi through forming MCETs. These cells can also eliminate fungi by phagocytosis. Finally, MCs seem necessary for the differentiation and activation of Th17 lymphocytes, a cell population with a leading role in antifungal immunity. The above-mentioned data strongly suggest that MCs act as initiators or regulators of inflammation during fungal infections. Additional support for this comes from some in vivo studies. However, there is a strong need to conduct more studies using MC-deficient experimental models that could provide additional elements for understanding the interaction between MCs and fungi. To date, it has been reported that the inherited MC deficiency in the experimental zymosan-induced peritonitis model significantly impaired the influx of leukocytes and the release of pro-inflammatory cytokines (including IL-1 $\beta$, IL-6, and TNF), suggesting that MCs initiate a cascade of inflammatory effects [99]. MCs may be involved in the morphine-mediated inhibition of zymosan-induced peritonitis in CBA mice as morphine promotes $\mathrm{MC}$ proliferation and/or migration during the early stages of this condition [100]. 


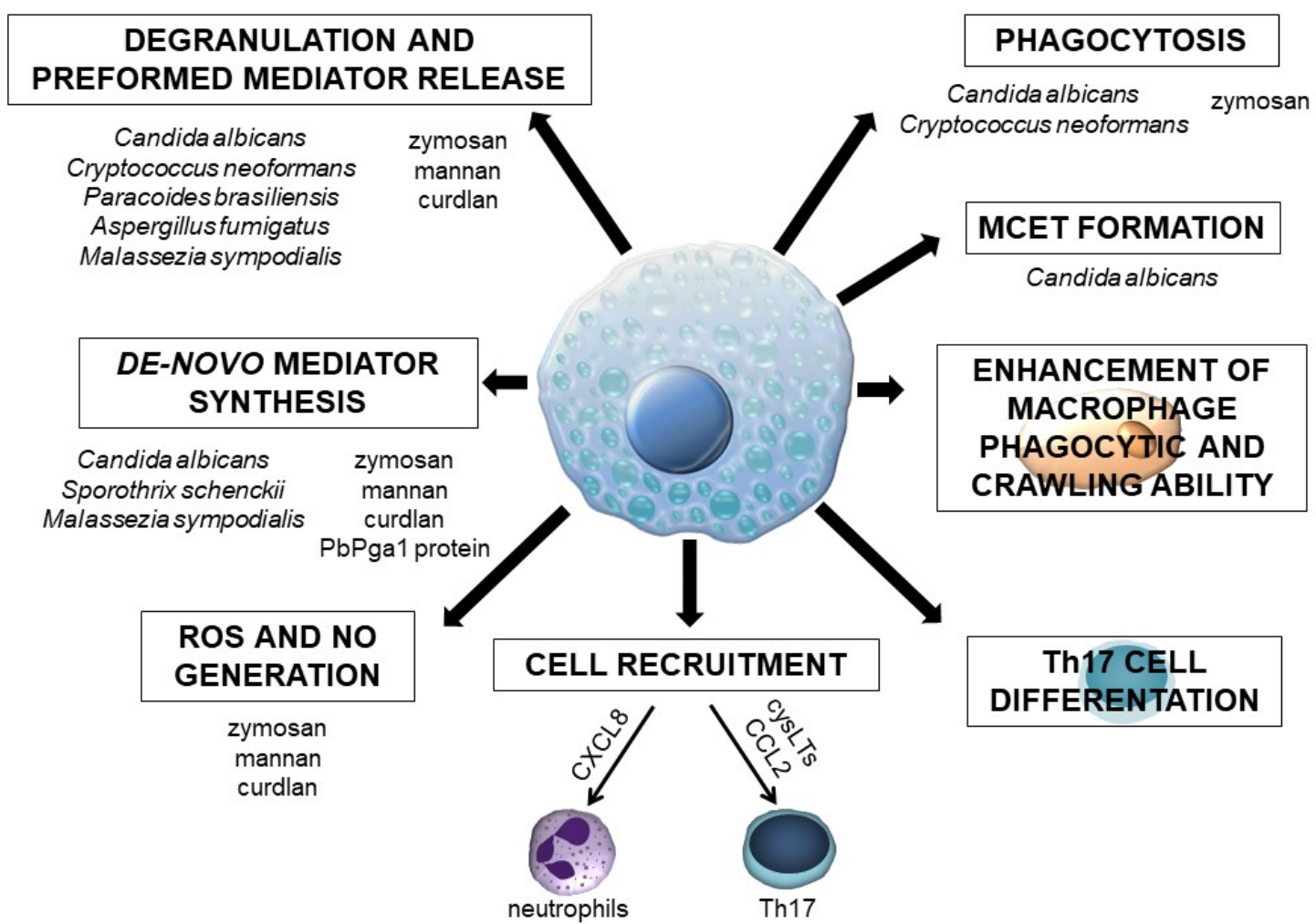

Figure 3. MC activities in response to fungi or fungus-derived molecules.

All these data allow the conclusion that MCs contribute to the control of fungal infections but may also orchestrate mobilization of cells involved in the innate and adaptive immune response. Undoubtedly, there is a strong need to conduct further studies that will help to understand exact MC mechanisms of action in antifungal host defense to develop and implement effective therapeutic strategies.

Author Contributions: Conceptualization, P.Ż., E.B.-B., and J.A.; writing-original draft preparation, P.Ż., J.P., and J.A.; writing-review and editing, P.Ż., J.P., E.B.-B., and J.A.; visualization, P.Ż.; supervision, E.B.-B. All authors have read and agreed to the published version of the manuscript.

Funding: This work was funded by the Medical University of Lodz, grant number 503/6-164-01/50361-001.

Institutional Review Board Statement: Not applicable.

Informed Consent Statement: Not applicable.

Data Availability Statement: Not applicable.

Conflicts of Interest: The authors declare no conflict of interest.

\section{References}

1. Rodrigues, M.L.; Nosanchuk, J.D. Fungal diseases as neglected pathogens: A wake-up call to public health officials. PLoS Negl. Trop. Dis. 2020, 14, e0007964. [CrossRef]

2. Von Lilienfeld-Toal, M.; Wagener, J.; Einsele, H.; Cornely, O.A.; Kurzai, O. Invasive fungal infection. Deutsches Ärzteblatt International 2019, 116, 271-278. [CrossRef]

3. Chin, V.K.; Yong, V.C.; Chong, P.P.; Nordin, S.A.; Basir, R.; Abdullah, M. Mycobiome in the gut: A multiperspective review. Mediat. Inflamm. 2020, 2020, 9560684. [CrossRef]

4. Gow, N.A.R.; Latge, J.-P.; Munro, C.A. The fungal cell wall: Structure, biosynthesis, and function. Microbiol. Spectr. 2017, 5, 1-25. [CrossRef] [PubMed]

5. Williams, P.B.; Barnes, C.S.; Portnoy, J.M.; Baxi, S.; Grimes, C.; Horner, W.E.; Kennedy, K.; Linnemann, D.L.; Levetin, E.; Miller, J.D.; et al. Innate and adaptive immune response to fungal products and allergens. J. Allergy Clin. Immunol. Pr. 2016, 4, 386-395. [CrossRef] [PubMed] 
6. Netea, M.G.; Joosten, L.A.B.; Van Der Meer, J.W.M.; Kullberg, B.-J.; Van De Veerdonk, F.L. Immune defence against Candida fungal infections. Nat. Rev. Immunol. 2015, 15, 630-642. [CrossRef]

7. Blanco, J.L.; Garcia, M. Immune response to fungal infections. Veter. Immunol. Immunopathol. 2008, 125, 47-70. [CrossRef] [PubMed]

8. Żelechowska, P.; Agier, J.; Brzezińska-Błaszczyk, E. Endogenous antimicrobial factors in the treatment of infectious diseases. Cent. Eur. J. Immunol. 2016, 4, 419-425. [CrossRef] [PubMed]

9. Chai, L.Y.A.; Netea, M.G.; Vonk, A.G.; Kullberg, B.-J. Fungal strategies for overcoming host innate immune response. Med. Mycol. 2009, 47, 227-236. [CrossRef] [PubMed]

10. Latgé, J.-P.; Beauvais, A.; Chamilos, G. The cell wall of the human fungal pathogen Aspergillus fumigatus: Biosynthesis, organization, immune response, and virulence. Annu. Rev. Microbiol. 2017, 71, 99-116. [CrossRef]

11. Sałkowska, A.; Karaś, K.; Walczak-Drzewiecka, A.; Dastych, J.; Ratajewski, M. Differentiation stage-specific effect of histone deacetylase inhibitors on the expression of ROR $\gamma \mathrm{T}$ in human lymphocytes. J. Leukoc. Biol. 2017, 102, 1487-1495. [CrossRef]

12. Leibovici, V.; Evron, R.; Axelrod, O.; Westerman, M.; Shalit, M.; Barak, V.; Frankenburg, S. Imbalance of immune responses in patients with chronic and widespread fungal skin infection. Clin. Exp. Dermatol. 1995, 20, 390-394. [CrossRef] [PubMed]

13. Netea, M.G.; Van Der Graaf, C.; Van Der Meer, J.W.M.; Kullberg, B.J. Recognition of fungal pathogens by toll-like receptors. Eur. J. Clin. Microbiol. Infect. Dis. 2004, 23, 672-676. [CrossRef]

14. Drummond, R.A.; Franco, L.M.; Lionakis, M.S. Human CARD9: A critical molecule of fungal immune surveillance. Front. Immunol. 2018, 9, 1836. [CrossRef] [PubMed]

15. Bruno, M.; Kersten, S.; Bain, J.M.; Jaeger, M.; Rosati, D.; Kruppa, M.D.; Lowman, D.W.; Rice, P.J.; Graves, B.; Ma, Z.; et al. Transcriptional and functional insights into the host immune response against the emerging fungal pathogen Candida auris. Nat. Microbiol. 2020, 5, 1516-1531. [CrossRef] [PubMed]

16. Hernández-Chávez, M.J.; Pérez-García, L.A.; Niño-Vega, G.A.; Mora-Montes, H.M. Fungal strategies to evade the host immune recognition. J. Fungi 2017, 3, 51. [CrossRef]

17. Pal, S.; Leger, R.J.S.; Wu, L. Fungal peptide destruxin a plays a specific role in suppressing the innate immune response in drosophila melanogaster. J. Biol. Chem. 2007, 282, 8969-8977. [CrossRef] [PubMed]

18. Urb, M.; Sheppard, D.C. The role of mast cells in the defence against pathogens. PLoS Pathog. 2012, 8, e1002619. [CrossRef]

19. Marshall, J.S. Mast-cell responses to pathogens. Nat. Rev. Immunol. 2004, 4, 787-799. [CrossRef]

20. Jiménez, M.; Cervantes-García, D.; Córdova-Dávalos, L.E.; Pérez-Rodríguez, M.J.; Gonzalez-Espinosa, C.; Salinas, E. Responses of mast cells to pathogens: Beneficial and detrimental roles. Front. Immunol. 2021, 12, 685865. [CrossRef] [PubMed]

21. Mukai, K.; Tsai, M.; Saito, H.; Galli, S.J. Mast cells as sources of cytokines, chemokines, and growth factors. Immunol. Rev. 2018, 282, 121-150. [CrossRef]

22. Moon, T.C.; Befus, A.D.; Kulka, M. Mast cell mediators: Their differential release and the secretory pathways involved. Front. Immunol. 2014, 5, 569. [CrossRef] [PubMed]

23. Atiakshin, D.; Buchwalow, I.; Tiemann, M. Mast cell chymase: Morphofunctional characteristics. Histochem. Cell Biol. 2019, 152, 253-269. [CrossRef]

24. Atiakshin, D.; Buchwalow, I.; Samoilova, V.; Tiemann, M. Tryptase as a polyfunctional component of mast cells. Histochem. Cell Biol. 2018, 149, 461-477. [CrossRef] [PubMed]

25. Thangam, E.B.; Jemima, E.A.; Singh, H.; Baig, M.S.; Khan, M.; Mathias, C.B.; Church, M.K.; Saluja, R. The role of histamine and histamine receptors in mast cell-mediated allergy and inflammation: The hunt for new therapeutic targets. Front. Immunol. 2018, 9, 1873. [CrossRef] [PubMed]

26. Möllerherm, H.; Von Köckritz-Blickwede, M.; Branitzki-Heinemann, K. Antimicrobial activity of mast cells: Role and relevance of extracellular DNA traps. Front. Immunol. 2016, 7, 265. [CrossRef]

27. Komi, D.E.A.; Kuebler, W.M. Significance of mast cell formed extracellular traps in microbial defense. Clin. Rev. Allergy Immunol. 2021, 22, 1-20. [CrossRef]

28. Garcia-Rodriguez, K.M.; Bahri, R.; Sattentau, C.; Roberts, I.S.; Goenka, A.; Bulfone-Paus, S. Human mast cells exhibit an individualized pattern of antimicrobial responses. Immun. Inflamm. Dis. 2020, 8, 198-210. [CrossRef]

29. Katsoulis-Dimitriou, K.; Kotrba, J.; Voss, M.; Dudeck, J.; Dudeck, A. Mast cell functions linking innate sensing to adaptive immunity. Cells 2020, 9, 2538. [CrossRef] [PubMed]

30. Agier, J.; Pastwińska, J.; Brzezińska-Błaszczyk, E. An overview of mast cell pattern recognition receptors. Inflamm. Res. 2018, 67, 737-746. [CrossRef]

31. Yu, M.; Song, X.-T.; Liu, B.; Luan, T.-T.; Liao, S.-L.; Zhao, Z.-T. The emerging role of mast cells in response to fungal infection. Front. Immunol. 2021, 12, 688659. [CrossRef] [PubMed]

32. Saluja, R.; Metz, M.; Maurer, M. Role and relevance of mast cells in fungal infections. Front. Immunol. 2012, 3, 146. [CrossRef] [PubMed]

33. Patin, E.C.; Thompson, A.; Orr, S.J. Pattern recognition receptors in fungal immunity. Semin. Cell Dev. Biol. 2019, 89, 24-33. [CrossRef] [PubMed]

34. Yang, Z.; Marshall, J.S. Zymosan treatment of mouse mast cells enhances dectin-1 expression and induces dectin-1-dependent reactive oxygen species (ROS) generation. Immunobiology 2009, 214, 321-330. [CrossRef] 
35. Olynych, T.J.; Jakeman, D.L.; Marshall, J.S. Fungal zymosan induces leukotriene production by human mast cells through a dectin-1-dependent mechanism. J. Allergy Clin. Immunol. 2006, 118, 837-843. [CrossRef] [PubMed]

36. Kimura, Y.; Chihara, K.; Honjoh, C.; Takeuchi, K.; Yamauchi, S.; Yoshiki, H.; Fujieda, S.; Sada, K. Dectin-1-mediated signaling leads to characteristic gene expressions and cytokine secretion via. spleen tyrosine kinase (Syk) in rat mast cells. J. Biol. Chem. 2014, 289, 31565-31575. [CrossRef] [PubMed]

37. Ribbing, C.; Engblom, C.; Lappalainen, J.; Lindstedt, K.; Kovanen, P.T.; Karlsson, M.A.; Lundeberg, L.; Johansson, C.; Nilsson, G.; Lunderius-Andersson, $\mathrm{C}$; et al. Mast cells generated from patients with atopic eczema have enhanced levels of granule mediators and an impaired Dectin-1 expression. Allergy 2010, 66, 110-119. [CrossRef] [PubMed]

38. Żelechowska, P.; Różalska, S.; Wiktorska, M.; Brzezińska-Błaszczyk, E.; Agier, J. Curdlan stimulates tissue mast cells to synthesize pro-inflammatory mediators, generate ROS, and migrate via. dectin-1 receptor. Cell. Immunol. 2020, 351, 104079. [CrossRef]

39. Agier, J.; Brzezińska-Błaszczyk, E.; Różalska, S.; Wiktorska, M.; Kozłowska, E.; Żelechowska, P. Mast cell phenotypic plasticity and their activity under the influence of cathelicidin-related antimicrobial peptide (CRAMP) and IL-33 alarmins. Cell. Immunol. 2021, 369, 104424. [CrossRef]

40. Honjoh, C.; Chihara, K.; Yoshiki, H.; Yamauchi, S.; Takeuchi, K.; Kato, Y.; Hida, Y.; Ishizuka, T.; Sada, K. Association of C-type lectin mincle with FceRI $\beta \gamma$ subunits leads to functional activation of RBL-2H3 cells through Syk. Sci. Rep. 2017, 7, 46064. [CrossRef]

41. Vukman, K.V.; Ravida, A.; Aldridge, A.M.; O'Neill, S.M. Mannose receptor and macrophage galactose-type lectin are involved in Bordetella pertussis mast cell interaction. J. Leukoc. Biol. 2013, 94, 439-448. [CrossRef]

42. McCurdy, J.D.; Lin, T.J.; Marshall, J.S. Toll-like receptor 4-mediated activation of murine mast cells. J. Leukoc. Biol. 2001, 70, 977-984. [PubMed]

43. Kubo, Y.; Fukuishi, N.; Yoshioka, M.; Kawasoe, Y.; Iriguchi, S.; Imajo, N.; Yasui, Y.; Matsui, N.; Akagi, M. Bacterial components regulate the expression of toll-like receptor 4 on human mast cells. Inflamm. Res. 2007, 56, 70-75. [CrossRef]

44. Matsushima, H.; Yamada, N.; Matsue, H.; Shimada, S. TLR3-, TLR7-, and TLR9-mediated production of proinflammatory cytokines and chemokines from murine connective tissue type skin-derived mast cells but not from bone marrow-derived mast cells. J. Immunol. 2004, 173, 531-541. [CrossRef] [PubMed]

45. Inomata, N.; Tomita, H.; Ikezawa, Z.; Saito, H. Differential gene expression profile between cord blood progenitor-derived and adult progenitor-derived human mast cells. Immunol. Lett. 2005, 98, 265-271. [CrossRef] [PubMed]

46. Agier, J.; Żelechowska, P.; Kozłowska, E.; Brzezińska-Błaszczyk, E. Expression of surface and intracellular toll-like receptors by mature mast cells. Cent. Eur. J. Immunol. 2016, 41, 333-338. [CrossRef]

47. Yoshioka, M.; Fukuishi, N.; Iriguchi, S.; Ohsaki, K.; Yamanobe, H.; Inukai, A.; Kurihara, D.; Imajo, N.; Yasui, Y.; Matsui, N.; et al. Lipoteichoic acid downregulates FceRI expression on human mast cells through toll-like receptor 2. J. Allergy Clin. Immunol. 2007, 120, 452-461. [CrossRef] [PubMed]

48. Mrabet-Dahbi, S.; Metz, M.; Dudeck, A.; Zuberbier, T.; Maurer, M. Murine mast cells secrete a unique profile of cytokines and prostaglandins in response to distinct TLR2 ligands. Exp. Dermatol. 2009, 18, 437-444. [CrossRef]

49. Kulka, M.; Alexopoulou, L.; Flavell, R.A.; Metcalfe, D.D. Activation of mast cells by double-stranded RNA: Evidence for activation through toll-like receptor 3. J. Allergy Clin. Immunol. 2004, 114, 174-182. [CrossRef] [PubMed]

50. Pietrzak, A.; Wierzbicki, M.; Wiktorska, M.; Brzezińska-Błaszczyk, E. Surface TLR2 and TLR4 expression on mature rat mast cells can be affected by some bacterial components and proinflammatory cytokines. Mediat. Inflamm. 2011, 2011, 427473. [CrossRef] [PubMed]

51. Okumura, S.; Kashiwakura, J.-I.; Tomita, H.; Matsumoto, K.; Nakajima, T.; Saito, H.; Okayama, Y. Identification of specific gene expression profiles in human mast cells mediated by toll-like receptor 4 and Fc $\in$ RI. Blood 2003, 102, 2547-2554. [CrossRef]

52. Yang, H.; Wei, J.; Zhang, H.; Song, W.; Wei, W.; Zhang, L.; Qian, K.; He, S. Upregulation of toll-like receptor (TLR) expression and release of cytokines from mast cells by IL-12. Cell. Physiol. Biochem. 2010, 26, 337-346. [CrossRef]

53. Agier, J.; Brzezińska-Błaszczyk, E.; Żelechowska, P.; Wiktorska, M.; Pietrzak, J.; Różalska, S. Cathelicidin LL-37 affects surface and intracellular toll-like receptor expression in tissue mast cells. J. Immunol. Res. 2018, 2018, 7357162. [CrossRef]

54. Yoshioka, M.; Fukuishi, N.; Kubo, Y.; Yamanobe, H.; Ohsaki, K.; Kawasoe, Y.; Murata, M.; Ishizumi, A.; Nishii, Y.; Matsui, N.; et al. Human cathelicidin CAP18/LL-37 changes mast cell function toward innate immunity. Biol. Pharm. Bull. 2008, 31, $212-216$. [CrossRef] [PubMed]

55. Nieto-Patlán, A.; Campillo-Navarro, M.; Rodríguez-Cortés, O.; Muñoz-Cruz, S.; Wong-Baeza, I.; Estrada-Parra, S.; Estrada-García, I.; Serafín-López, J.; Chacón-Salinas, R. Recognition of Candida albicans by dectin-1 induces mast cell activation. Immunobiol. 2015, 220, 1093-1100. [CrossRef]

56. Sakurai, A.; Yamaguchi, N.; Sonoyama, K. Cell wall polysaccharides of Candida albicans induce mast cell degranulation in the gut. Biosci. Microbiota Food Health 2012, 31, 67-70. [CrossRef] [PubMed]

57. Lopes, J.P.; Stylianou, M.; Nilsson, G.; Urban, C.F. Opportunistic pathogen Candida albicans elicits a temporal response in primary human mast cells. Sci. Rep. 2015, 5, 12287. [CrossRef] [PubMed]

58. Urb, M.; Pouliot, P.; Gravelat, F.N.; Olivier, M.; Sheppard, D.C. Aspergillus fumigatus induces immunoglobulin e-independent mast cell degranulation. J. Infect. Dis. 2009, 200, 464-472. [CrossRef] 
59. Renga, G.; Moretti, S.; Oikonomou, V.; Borghi, M.; Zelante, T.; Paolicelli, G.; Costantini, C.; De Zuani, M.; Villella, V.R.; Raia, V.; et al. IL-9 and mast cells are key players of Candida albicans commensalism and pathogenesis in the gut. Cell Rep. 2018, 23, 1767-1778. [CrossRef] [PubMed]

60. De Zuani, M.; Paolicelli, G.; Zelante, T.; Renga, G.; Romani, L.; Arzese, A.; Pucillo, C.E.M.; Frossi, B. Mast cells respond to Candida albicans infections and modulate macrophages phagocytosis of the fungus. Front. Immunol. 2018, 9, 2829. [CrossRef] [PubMed]

61. Lopes, J.P.; Stylianou, M.; Backman, E.; Holmberg, S.; Ekoff, M.; Nilsson, G.; Urban, C.F. Cryptococcus neoformans induces MCP-1 release and delays the death of human mast cells. Front. Cell. Infect. Microbiol. 2019, 9, 289. [CrossRef] [PubMed]

62. Selander, C.; Engblom, C.; Nilsson, G.; Scheynius, A.; Andersson, C.L. TLR2/MyD88-dependent and -independent activation of mast cell IgE responses by the skin commensal yeast Malassezia sympodialis. J. Immunol. 2009, 182, 4208-4216. [CrossRef] [PubMed]

63. Valim, C.X.R.; Da Silva, E.Z.M.; Assis, M.A.; Fernandes, F.F.; Coelho, P.S.R.; Oliver, C.; Jamur, M.C. rPbPga1 from Paracoccidioides brasiliensis activates mast cells and macrophages via. NFkB. PLoS Negl. Trop. Dis. 2015, 9, e0004032. [CrossRef]

64. Romo-Lozano, Y.; Hernández-Hernández, F.; Salinas, E. Sporothrix schenckii yeasts induce ERK pathway activation and secretion of IL-6 and TNF- $\alpha$ in rat mast cells, but no degranulation. Med. Mycol. 2014, 52, 862-868. [CrossRef] [PubMed]

65. Romo-Lozano, Y.; Hernández-Hernández, F.; Salinas, E.; Salinas, E. Mast cell activation by conidia of Sporothrix schenckii: Role in the severity of infection. Scand. J. Immunol. 2012, 76, 11-20. [CrossRef] [PubMed]

66. Jiao, Q.; Luo, Y.; Scheffel, J.; Geng, P.; Wang, Y.; Frischbutter, S.; Li, R.; Maurer, M.; Zhao, Z. Skin mast cells contribute to Sporothrix schenckii infection. Front. Immunol. 2020, 11, 469. [CrossRef] [PubMed]

67. Gomez, C.; Carsin, A.; Gouitaa, M.; Reynaud-Gaubert, M.; Dubus, J.-C.; Mège, J.-L.; Ranque, S.; Vitte, J. Mast cell tryptase changes with Aspergillus fumigatus_host crosstalk in cystic fibrosis patients. J. Cyst. Fibros. 2018, 17, 631-635. [CrossRef] [PubMed]

68. Atiakshin, D.; Buchwalow, I.; Tiemann, M. Mast cells and collagen fibrillogenesis. Histochem. Cell Biol. 2020, 154, 21-40. [CrossRef] [PubMed]

69. Alshahrani, M.Y.; Alfaifi, M.; Al Shahrani, M.; Alshahrani, A.S.; Alkhathami, A.G.; Dera, A.A.; Ahmad, I.; Wahab, S.; Beg, M.M.A.; Hakamy, A.; et al. Increased mRNA expression of key cytokines among suspected cases of Pneumocystis jirovecii infection. BMC Infect. Dis. 2021, 21, 28. [CrossRef] [PubMed]

70. Khodavaisy, S.; Mortaz, E.; Mohammadi, F.; Aliyali, M.; Fakhim, H.; Badali, H. Pneumocystis jirovecii colonization in chronic obstructive pulmonary disease (COPD). Curr. Med. Mycol. 2015, 1, 42-48. [CrossRef]

71. Aponte-López, A.; Muñoz-Cruz, S. Mast cells in the tumor microenvironment. Adv. Exp. Med. Biol. 2020, 1273, 159-173. [CrossRef]

72. Komi, D.E.A.; Redegeld, F.A. Role of mast cells in shaping the tumor microenvironment. Clin. Rev. Allergy Immunol. 2019, 58, 313-325. [CrossRef]

73. Di Cosola, M.; Cazzolla, A.; Charitos, I.; Ballini, A.; Inchingolo, F.; Santacroce, L. Candida albicans and oral carcinogenesis. A brief review. J. Fungi 2021, 7, 476. [CrossRef] [PubMed]

74. Trevisan, E.; Vita, F.; Medic, N.; Soranzo, M.R.; Zabucchi, G.; Borelli, V. Mast cells kill Candida albicans in the extracellular environment but spare ingested fungi from death. Inflammation 2014, 37, 2174-2189. [CrossRef]

75. Yan, Y.; Zhao, Z.; Wan, H.; Wu, R.; Fang, J.; Liu, H. A novel fungus concentration-dependent rat model for acute invasive fungal rhinosinusitis: An experimental study. BMC Infect. Dis. 2014, 14, 3856. [CrossRef] [PubMed]

76. Xie, Y.; Zhang, H.; Liu, S.; Chen, G.; He, S.; Li, Z.; Wang, L. Mast cell activation protects cornea by promoting neutrophil infiltration via. stimulating ICAM-1 and vascular dilation in fungal keratitis. Sci. Rep. 2018, 8, 8365. [CrossRef] [PubMed]

77. Marangon, A.V.; Svidzinski, T.I.E.; Salci, T.P.; Meurer, R.; Fernandes, M.D.C.; Hernandes, L. Metabolic extract of Fusarium oxysporum induces histopathologic alterations and apoptosis in the skin of wistar rats. Int. J. Dermatol. 2009, 48, 697-703. [CrossRef] [PubMed]

78. Pinke, K.H.; de Lima, H.G.; Cunha, F.Q.; Lara, V.S. Mast cells phagocyte Candida albicans and produce nitric oxide by mechanisms involving TLR2 and Dectin-1. Immunobiology 2016, 221, 220-227. [CrossRef] [PubMed]

79. Padawer, J.; Fruhman, G.J. Phagocytosis of zymosan particles by mast cells. Cell. Mol. Life Sci. 1968, 24, 471-472. [CrossRef] [PubMed]

80. Nosál, R.; Novotný, J.; Sikl, D. The effect of glycoprotein from Candida albicans on isolated rat mast cells. Toxicon 1974, 12, 103-106. [CrossRef]

81. Yamaki, K.; Yoshino, S. Aspergillus oryzae lectin induces anaphylactoid oedema and mast cell activation through its interaction with fucose of mast cell-bound non-specific IgE. Scand. J. Immunol. 2011, 74, 445-453. [CrossRef] [PubMed]

82. Żelechowska, P.; Brzezińska-Błaszczyk, E.; Różalska, S.; Agier, J.; Kozłowska, E. Mannan activates tissue native and IgE-sensitized mast cells to proinflammatory response and chemotaxis in TLR4-dependent manner. J. Leukoc. Biol. 2021, 109, 931-942. [CrossRef]

83. Żelechowska, P.; Brzezińska-Błaszczyk, E.; Różalska, S.; Agier, J.; Kozłowska, E. Native and IgE-primed rat peritoneal mast cells exert pro-inflammatory activity and migrate in response to yeast zymosan upon dectin-1 engagement. Immunol. Res. 2021, 69, 176-188. [CrossRef] [PubMed]

84. McCurdy, J.D.; Olynych, T.J.; Maher, L.H.; Marshall, J.S. Cutting edge: Distinct toll-like receptor 2 activators selectively induce different classes of mediator production from human mast cells. J. Immunol. 2003, 170, 1625-1629. [CrossRef] [PubMed] 
85. Sato, H.; Kobayashi, Y.; Hattori, A.; Suzuki, T.; Shigekawa, M.; Jippo, T. Inhibitory effects of water-soluble low-molecular-weight $\beta-(1,3-1,6)$ D-glucan isolated from Aureobasidium pullulans 1A1 strain black yeast on mast cell degranulation and passive cutaneous anaphylaxis. Biosci. Biotechnol. Biochem. 2012, 76, 84-88. [CrossRef]

86. Niide, O.; Suzuki, Y.; Yoshimaru, T.; Inoue, T.; Takayama, T.; Ra, C. Fungal metabolite gliotoxin blocks mast cell activation by a calcium- and superoxide-dependent mechanism: Implications for immunosuppressive activities. Clin. Immunol. 2006, 118, 108-116. [CrossRef]

87. Barbosa-Lorenzi, V.C.; Peyda, S.; Scheynius, A.; Nilsson, G.; Lunderius-Andersson, C. Curdlan induces selective mast cell degranulation without concomitant release of LTC 4, IL-6 or CCL2. Immunobiology 2017, 222, 647-650. [CrossRef]

88. Tung, H.-Y.; Plunkett, B.; Huang, S.-K.; Zhou, Y. Murine mast cells secrete and respond to interleukin-33. J. Interf. Cytokine Res. 2014, 34, 141-147. [CrossRef]

89. Zelante, T.; De Luca, A.; Angelo, C.D.; Moretti, S.; Romani, L. IL-17/Th17 in anti-fungal immunity: What's new? Eur. J. Immunol. 2009, 39, 645-648. [CrossRef]

90. Sparber, F.; Leibund Gut-Landmann, S. Interleukin-17 in antifungal immunity. Pathogens 2019, 8, 54. [CrossRef] [PubMed]

91. Suurmond, J.; Habets, K.L.L.; Dorjée, A.L.; Huizinga, T.W.; Toes, R.E.M. Expansion of Th17 cells by human mast cells is driven by inflammasome-independent IL-1 $\beta$. J. Immunol. 2016, 197, 4473-4481. [CrossRef] [PubMed]

92. Nakae, S.; Suto, H.; Berry, G.J.; Galli, S.J. Mast cell-derived TNF can promote Th17 cell-dependent neutrophil recruitment in ovalbumin-challenged OTII mice. Blood 2006, 109, 3640-3648. [CrossRef] [PubMed]

93. Cho, K.-A.; Suh, J.W.; Sohn, J.H.; Park, J.W.; Lee, H.; Kang, J.L.; Woo, S.-Y.; Cho, Y.J. IL-33 induces Th17-mediated airway inflammation via. mast cells in ovalbumin-challenged mice. Am. J. Physiol. Cell. Mol. Physiol. 2012, 302, L429-L440. [CrossRef] [PubMed]

94. Mommert, S.; Gschwandtner, M.; Koether, B.; Gutzmer, R.; Werfel, T. Human memory Th17 cells express a functional histamine H4 receptor. Am. J. Pathol. 2012, 180, 177-185. [CrossRef]

95. Lee, W.; Kim, H.S.; Lee, G.R. Leukotrienes induce the migration of Th17 cells. Immunol. Cell Biol. 2014, 93, 472-479. [CrossRef]

96. Wang, A.; Wang, Z.; Cao, Y.; Cheng, S.; Chen, H.; Bunjhoo, H.; Xie, J.; Wang, C.; Xu, Y.; Xiong, W. CCL2/CCR2-dependent recruitment of Th17 cells but not Tc17 cells to the lung in a murine asthma model. Int. Arch. Allergy Immunol. 2015, 166, 52-62. [CrossRef]

97. Dudeck, A.; Suender, C.A.; Kostka, S.L.; von Stebut, E.; Maurer, M. Mast cells promote Th1 and Th17 responses by modulating dendritic cell maturation and function. Eur. J. Immunol. 2011, 41, 1883-1893. [CrossRef] [PubMed]

98. Cho, K.-A.; Park, M.; Kim, Y.-H.; Woo, S.-Y. Th17 cell-mediated immune responses promote mast cell proliferation by triggering stem cell factor in keratinocytes. Biochem. Biophys. Res. Commun. 2017, 487, 856-861. [CrossRef]

99. Kolaczkowska, E.; Seljelid, R.; Plytycz, B. Role of mast cells in zymosan-induced peritoneal inflammation in Balb/c and mast cell-deficient WBB6F1 mice. J. Leukoc. Biol. 2001, 69, 33-42.

100. Wypasek, E.; Natorska, J.; Stankiewicz, E.; Kolaczkowska, E. Morphine-modulated mast cell migration and proliferation during early stages of zymosan-induced peritonitis in CBA mice. Folia Biol. 2011, 59, 99-106. [CrossRef] 